DOI 10.18551/rjoas.2019-01.57

\title{
PERFORMANCE ANALYSIS OF ISLAMIC MUTUAL FUND AND CONVENTIONAL MUTUAL FUND LISTED IN OTORITAS JASA KEUANGAN IN INDONESIA
}

\author{
Widiyanti Marlina*, Isnurhadi \\ Management Study Program, Economic Faculty, University of Sriwijaya, Indonesia \\ *E-mail: marlinawidiyanti68@yahoo.co.id
}

\begin{abstract}
This study will describe the performance analysis of stock mutual funds in two different market conditions, namely when market conditions are bullish and market conditions are bearish. In addition, this study also compares the performance results of stock mutual funds with benchmark performance (IHSG and LQ45) to find out which equity funds include outperform or underperform. This research will be conducted on stock mutual funds listed on the Indonesia Stock Exchange and operating in 2014 until 2017. The research methods used in this study are Sharpe, Treynor and Jensen methods. The results of this study indicate that the average stock mutual fund in bullish conditions has an outperform performance with the Jensen method, while the average stock mutual fund in bearish conditions has a performance with the Treynor method. In the bullish conditions the best performing mutual funds are Archipelago Equity Growth, while in the bearish condition the best performing equity fund is the GAP Value Fund. The results of this study also show that there are differences between the performance of equity funds with Sharpe, Treynor, and Jensen methods.
\end{abstract}

\section{KEY WORDS}

Islamic mutual funds, conventional mutual funds, Sharpe method, Treynor method, Jensen method.

Stock mutual funds have developed into one of the most promising investment alternatives. The many advantages offered by Mutual Funds make the development of this type of Mutual Fund grow so rapidly. Investors increasingly believe that investing in equity funds can provide high potential profits. This study seeks to analyze the performance of equity funds in two market conditions, namely bullish and bearish conditions. The hope of this research is that investors and prospective investors can find out the ability of equity funds in different market conditions. This study uses the Sharpe, Treynor and Jensen methods as an analysis of the performance measurement of stock mutual funds. The three methods have different characteristics so that investors can assess the performance of stock mutual funds from various perspectives. This study also compares the performance of stock mutual funds with benchmark performance (IHSG and LQ45) to see which equity funds are included in outperform or underperform.

Lots of investors and potential investors are careless in choosing the best performing equity funds. Many of them did not analyze the performance of stock mutual funds before starting to invest. Many investors are interested in investing in equity funds because they trust the closest people. This situation is exacerbated by the rarity of information regarding the analysis of the performance of publicly-traded equity funds and the number of investors who do not know how to properly analyze the performance of equity funds. Investors and potential investors will easily be swayed in situations like this and cause mistakes in making investment decisions.

The problem of choosing a equity fund does not stop here only. The recent unstable effects of stock market movements also add to the confusion experienced by investors and potential investors. Returns on equity funds are difficult to predict because of this situation. Investors must always be on guard by continuing to monitor the performance of stock mutual funds on a regular basis in order to protect the funds invested. It becomes a special difficulty 
for ordinary people in choosing equity fund products that are right when market conditions like this.

Looking at the various problems that exist, it is very important to do an up-to-date study on the analysis of the performance of equity funds to help investors and potential investors in making investment decisions. This study will describe the performance analysis of stock mutual funds in two different market conditions, namely when market conditions are bullish and market conditions are bearish. Bullish is a condition when the market experiences an upward trend, while bearish is a market condition when it experiences a downward trend. The hope of this research is that investors and potential investors can choose the best performing equity funds and know the ability of equity funds in different market conditions. Investors and prospective investors can also see the characteristics of Investment Managers in managing their investment funds.

\section{LITERATURE REVIEW}

A.B.M. Munibur Rahman, Prof. Fang Qiang and Suborna Barua (2012) with the results that the performance of mutual funds in Bangladesh showed better results using the Jensen and Treynor methods, but with the Sharpe method it showed a significant difference.

Praveen K. Das and S.P. Uma Rao (2013) with the Sharpe method that shows the results of 94 samples used by mutual funds is not good for social responsibility, and the selection of mutual funds can provide an opportunity to fund managers to identify the best companies in terms of financial performance in the future.

Raheel Mumtaz, Muhammad Usman \& Saad Bin Nasir (2014) The results of the research show that there is superior funding selectivity ability but inferior market timing expertise between Islamic fund managers in the study period.

Uun Sunarsih and Andriyanto (2015) with Sharpe, Treynor, and Jensen methods that analyzed the performance of Islamic mutual funds showed that the performance of Islamic mutual funds is worthy of being an investment choice. And the positive return of returns gives investors an advantage and the negative return is a loss for investors.

Elliv Hidayatul Lailiyah, Suhadak and Sri Sulasmiyati (2016) the results obtained using the Sharpe, Traylor, and Jenes methods and AUM growth are the performance of conventional mutual funds better than the performance of Islamic mutual funds.

Ahmed Sakr (2017) this study shows a positive correlation between the quality of mutual product governance and dividend policy as measured by dividend yield.

\section{METHODS OF RESEARCH}

This research seeks to determine the performance characteristics of stock mutual funds with IHSG and LQ45 as benchmarks for equity funds in two different market conditions, namely bullish and bearish market conditions.

This research will be carried out on equity mutual funds listed on the Indonesia Stock Exchange and operating in 2014 until 2017. Data collection is downloaded using the internet on the site www.pusatdata.kontan.co.id for equity funds NAV data, www.finance. yahoo.com for IHSG and LQ45 data and www.bi.go.id for BI rate data.

The research method used in this study is the Sharpe method, Treynor method and Jensen's method. Through these three methods, investors and prospective investors can analyze the performance of shares through the level of profit and risk of a equity fund, so that investors and potential investors know the ability of the Investment Manager to manage investment funds. The three methods have different characteristics. The Sharpe method uses individual risk (standard deviation) as the basis for the test. The Treynor method emphasizes beta, while the Jensen method uses alpha as the basis for testing (Wahdah, 2012). 


\section{RESULTS AND DISCUSSION}

The results of data analysis using the Mann-Whitney test for hypothesis testing are shown in the following table:

Table 1 - Statistical Test (Sharpe method)

\begin{tabular}{|c|c|}
\hline n/n & METODE_SHARPE \\
\hline Mann-Whitney U & 200,000 \\
\hline Wilcoxon W & 431,000 \\
\hline Z &,- 516 \\
\hline Asymp. Sig. (2-tailed) &, 606 \\
\hline a. Grouping Variable: BULLIST_BEARIST & \\
\hline
\end{tabular}

The results of the Mann-Whitney test show that the numbers in the Asymp column. Sig for the calculation of the performance of mutual funds with Sharpe's performance measure is 0.606 or in other words Sig 0.05 then $\mathrm{HO}$ is accepted. This shows that there is a difference between the performances of stock mutual funds using the Sharpe method.

Table 2 - Statistical Test (Treynor Method)

\begin{tabular}{|c|c|}
\hline n/n & METODE_TREYNOR_IHSG \\
\hline Mann-Whitney U & 167,000 \\
\hline Wilcoxon W & 398,000 \\
\hline Z & $-1,346$ \\
\hline Asymp. Sig. (2-tailed) &, 178 \\
\hline a. Grouping Variable: BULLIST_BEARIST & \\
\hline
\end{tabular}

The results of the Mann-Whitney test show that the numbers in the Asymp column. Sig for the calculation of mutual fund performance with Treynor performance measure is worth 0.178 or in other words $\mathrm{Sig}>0.05$ then $\mathrm{HO}$ is accepted. This shows that there is a difference between the performances of stock mutual funds, if using the Treynor method.

Table 3 - Statistical Test (Treynor Method)

\begin{tabular}{|c|c|}
\hline $\mathrm{n} / \mathrm{n}$ & METODE_TREYNOR_LQ45 \\
\hline Mann-Whitney U & 157,500 \\
\hline Wilcoxon W & 388,500 \\
\hline Z & $-1,585$ \\
\hline Asymp. Sig. (2-tailed) &, 113 \\
\hline a. Grouping Variable: BULLIST_BEARIST & \\
\hline
\end{tabular}

The results of the Mann-Whitney test show that the numbers in the Asymp column. Sig for the calculation of the performance of mutual funds with Treynor performance measures worth 0.113 or in other words Sig 0.05 then $\mathrm{HO}$ is accepted. This shows that there is a difference between the performances of stock mutual funds, if using the Treynor method.

Table 4 - Statistical Test (Jensen Method)

\begin{tabular}{|c|c|}
\hline $\mathrm{n} / \mathrm{n}$ & METODE_JENSEN_IHSG \\
\hline Mann-Whitney U & 197,000 \\
\hline Wilcoxon W & 428,000 \\
\hline Z &,- 591 \\
\hline Asymp. Sig. (2-tailed) &, 554 \\
\hline a. Grouping Variable: BULLIST_BEARIST & \\
\hline
\end{tabular}

The results of the Mann-Whitney test show that the numbers in the Asymp column. Sig for the calculation of the performance of mutual funds with Treynor performance measures worth 0.554 or in other words Sig $>0.05$ then $\mathrm{HO}$ is accepted. This shows that there is a difference between the performances of stock mutual funds, if using the Jensen method. 
Table 5 - Statistical Test (Jensen Method)

\begin{tabular}{|c|c|}
\hline n/n & METODE_JENSEN_LQ45 \\
\hline Mann-Whitney U & 146,000 \\
\hline Wilcoxon W & 377,000 \\
\hline Z & $-1,874$ \\
\hline Asymp. Sig. (2-tailed) &, 061 \\
\hline a. Grouping Variable: BULLIST_BEARIST & \\
\hline
\end{tabular}

The results of the Mann-Whitney test show that the numbers in the Asymp column. Sig for the calculation of the performance of mutual funds with Treynor performance measures worth 0.061 or in other words Sig $>0.05$ then $\mathrm{HO}$ is accepted. This shows that there is a difference between the performances of stock mutual funds, if using the Jensen method.

Table 6 - Recapitulation of Analysis of Different Tests of Sharia Mutual Funds and Conventional Funds

\begin{tabular}{cc}
\hline Method of Sharpe & Sig. (2-tailed) $(0,606)>\alpha(0,05)$ \\
\hline Method of Treynor & Sig. (2-tailed) $(0,178)>\alpha(0,05)$ \\
\hline Method of Jensen & Sig. (2-tailed) $(0,554)>\alpha(0,05)$ \\
\hline
\end{tabular}

Source: data processed by researchers.

The Mann Whitney test shows that the Sharpe method has a significant level of $0.606>$ 0.05 , so that $\mathrm{Ho}$ is accepted and $\mathrm{Ha}$ is rejected, meaning there is a difference between the performance of equity funds based on the Sharpe method. While the Treynor method has a significant level of $0.178>0.05$, so $\mathrm{Ho}$ is accepted and $\mathrm{Ha}$ is rejected, meaning there is a difference between the performances of stock mutual funds based on the Treynor method. The Jensen method has a significant level of $0.554>0.05$, so $\mathrm{Ho}$ is accepted and $\mathrm{Ha}$ is rejected, meaning that there is a difference between the performance of equity funds based on the Jensen method. This can be caused by bullish and bearish conditions there are differences in the number of investors or the decrease in return.

\section{CONCLUSION}

Based on the results of the research and the discussion that has been done, conclusions can be taken as follows:

- The Sharpe method shows that the performance of stock mutual funds in bullish 5 mutual funds has a positive value while in a bearish condition 6 mutual funds have a positive value;

- The Treynor method shows that the performance of equity funds in bullish conditions of 14 mutual funds has a positive value while in bearish conditions 9 mutual funds have a positive value;

- The Jensen method shows the performance of mutual funds in bullish conditions of 4 mutual funds having a positive value while in bearish conditions 3 mutual funds have a positive value;

- The results of this study indicate that the average stock mutual fund in bullish conditions has an outperform performance with the Jensen method, while the average stock mutual fund in bearish conditions has a performance performance with the Treynor method. In the bullish condition the best performing mutual fund is Archipelago Equity Growth, while the bearish condition of equity funds with the best performance is the GAP Value Fund;

- The results of this study also indicate that there are differences between the performance of equity funds with Sharpe, Treynor, and Jensen methods. 


\section{REFERENCES}

1. Das, Praveen K, \& S.P. Uma, Rao. (2013). Performance evaluation of socially responsible mutual funds using style analysis. http://doi.org/10.1108/17471111311307840

2. Lailiyah, Elliv Hidayatul, dkk. (2016).Analisis Perbandingan Kinerja Reksadana Syariah Dan Reksadana Konvensional (Studi Pada Reksadana Yang Terdaftar Di Otoritas Jasa Keuangan Periode 2012-2016).Jurnal Administrasi Bisnis (JAB)|Vol. 35 No. 2 Juni 2016| administrasibisnis.studentjournal.ub.ac.id, p.114-121.

3. Mumtaz, R., Usman, M., \& Nasir, S. Bin. (2014). An Empirical Study of Risk-Return Profile of Islamic Mutual Funds : A Case from Pakistan, 6 (20), 156-168.

4. Otoritas Jasa Keuangan. (2016). Data Reksa Dana http://www.ojk.go.id. Diakses pada 18 Maret 2018.

5. Rahman, A. B. M. M., Fang, P., \& Suborna, Q. (2012). Mutual Fund Performance: An Analysis of Monthly Returns of an Emerging Market, 3(4), 34-47.

6. Sakr, A., \& Youssef, N. (2017). The Effect of Corporate Governance on Mutual Fund Dividend Policy : Evidence from Egypt, 8(4), 122-135.

7. Sunarsih, U. (2015). Analysis of the Performance of Islamic Mutual Funds in Indonesia by using Sharpe, Treynor and Jensen the Period 2010- 2012. Research Journal of Finance and Accounting, 6(3), p.125-134. 